\title{
A test battery for assessing the ecotoxic effects of textile dyes
}

\author{
Gisele Augusto Rodrigues de Oliveira ${ }^{\mathrm{a}, \mathrm{f}, *, 1}$, Daniela Morais Leme ${ }^{\mathrm{b}, \mathrm{f}, 1}$, Joaquín de Lapuente ${ }^{\mathrm{c}}$, \\ Lara Barroso Brito ${ }^{a}$, Constança Porredón ${ }^{c}$, Laís de Brito Rodrigues ${ }^{\mathrm{a}}$, Natália Brull ${ }^{\mathrm{c}}$, \\ Joan Txu Serret ${ }^{\mathrm{c}}$, Miquel Borràs ${ }^{\mathrm{d}}$, Geonildo Rodrigo Disner ${ }^{\mathrm{b}}$, Marta Margarete Cestari ${ }^{\mathrm{b}}$, \\ Danielle Palma de Oliveira ${ }^{\mathrm{e}, \mathrm{f}}$ \\ a Faculty of Pharmacy (FF), Federal University of Goiás (UFG), Goiânia, GO, Brazil \\ ${ }^{\mathrm{b}}$ Departament of Genetics, Federal University of Paraná (UFPR), Curitiba, PR, Brazil \\ ${ }^{\mathrm{c}}$ Unit of Experimental Toxicology and Ecotoxicology (UTOX), Barcelona Science Park (PCB), Barcelona, Spain \\ d Association of Biologists of Catalonia (CBC), Barcelona, Spain \\ e Faculty of Pharmaceutical Sciences of Ribeirão Preto (FCFRP), University of São Paulo (USP), Ribeirão Preto, SP, Brazil \\ ${ }^{\mathrm{f}}$ National Institute for Alternative Technologies of Detection, Toxicological Evaluation and Removal of Micropollutants and Radioactives (INCT-DATREM), UNESP, \\ Institute of Chemistry, P.O. Box 355, 14800-900, Araraquara, SP, Brazil
}

\begin{abstract}
A B S T R A C T
The textile dyeing industry is one of the main sectors contributing to environmental pollution, due to the generation of large amounts of wastewater loaded with dyes (ca. $2-50 \%$ of the initial amount of dyes used in the dye baths is lost), causing severe impacts on human health and the environment. In this context, an ecotoxicity testing battery was used to assess the acute toxicity and genotoxicity of the textile dyes Direct Black 38 (DB38; azo dye) and Reactive Blue 15 (RB15; copper phthalocyanine dye) on different trophic levels. Thus these dyes were tested using the following assays: Filter paper contact test with earthworms (Eisenia foetida); seed germination and root elongation toxicity test (Cucumis sativus, Lactuca sativa and Lycopersicon esculentum); acute immobilization test (Daphnia magna and Artemia salina); and the Comet assay with the rainbow trout gonad-2 cell fish line (RTG-2) and D. magna. Neither phytotoxicity nor significant effects on the survival of $E$. foetida were observed after exposure to DB38 and RB15. Both dyes were classified as relatively non-toxic to $D$. magna $\left(\mathrm{LC}_{50}>100 \mathrm{mg} / \mathrm{L}\right)$, but DB38 was moderately toxic to A. salina with a $\mathrm{LC}_{50}$ of $20.7 \mathrm{mg} / \mathrm{L}$. DB38 and RB15 induced significant effects on the DNA of D. magna but only DB38 caused direct (alkaline comet assay) and oxidative (hOGG1-modified alkaline comet assay) damage to RTG-2 cells in hormetic responses. Therefore, the present results emphasize that a test battery approach of bioassays representing multiple trophic levels is fundamental in predicting the toxicity of textile dyes, aside from providing the information required to define their safe levels for living organisms in the environment.
\end{abstract}

\section{Introduction}

The textile industry plays an important role in the economy of many countries, providing a vast range of colored fabrics for marketing, but its manufacturing activities pose challenges for environmental management, since large amounts of synthetic dyes, resistant to conventional wastewater treatments, are daily released into the environment [1-7]. The amount of dye that is released into the textile effluents may vary from $2 \%$ to $50 \%$ of the initial dye concentration $[3,8]$.

Thus dye-based toxicity has been investigated over the years in order to identify hazardous dyes and, consequently, to protect human health and the environment [3-5,9-15]. However, most of the studies on dye toxicity have focused on humans, and safe thresholds to protect environmental organisms are not available for most of the dyes commonly used in textile dyeing $[6,14]$. For example, Direct Black 38 (DB38) is an azo dye classified as carcinogenic to humans due to its biotransformation to benzidine [16-18], but there is a lack of data on its impact to terrestrial and aquatic organisms. Recently, Oliveira and co-authors [5] pointed out that care should be taken in discharging DB38-containing wastewater, since this dye has been shown to be embryotoxic for the zebrafish model. Reactive Blue 15 (RB15), a copper-phthalocyanine dye, is toxic for the bacteria, tadpoles and embryo fish models $[5,19,20]$. The identification of its toxicity for species covering other trophic levels is relevant to gather additional

\footnotetext{
* Corresponding author. Rua 240, s/n, Setor Leste Universitário, 74605-170, Goiânia, Goiás, Brazil.

E-mail addresses: gaugusto@ufg.br (G.A.R.d. Oliveira), daniela.leme@ufpr.br (D.M. Leme).

${ }^{1}$ These authors participated equally in this research.
} 
ecotoxicological knowledge, and hence determine its safe level to protect the environment. Species-specific toxicity has already been demonstrated for Reactive Red 120, which reinforces the use of a multiple trophic levels eco-tests approach to accurately predict the ecotoxic effects of textile dyes [4].

One of the core missions of ecotoxicology is to understand the underlying mechanisms behind pollutants that can disturb the normal physiological condition of biological systems, in order to prevent adverse outcomes resulting from them [21]. Thus short-term assays are useful ecotoxicological tools for estimating the acute toxicity caused by environmental chemicals.

Plants are the foundation of terrestrial and aquatic ecosystems, acting as primary producers in the food chain [22]. Thus, phytotoxicity tests are a vital part of ecotoxicological assessment, the seed germination and root elongation test being the simplest one, and representative of the action of the toxicant at the first interface of the developing plant (seed) and its environment [23]. Earthworms (terrestrial invertebrate) are considered to be suitable indicator species for ecotoxicological assessment, since they may represent $60-80 \%$ of the total soil biomass and play crucial roles in soil functioning (e.g. aeration, moisture content, nutrient cycling), apart from being sensitive to low toxicant concentrations [24,25]. Thus the acute earthworm toxicity test using Eisenia foetida or Eisenia andrei has been recommended for detecting potential soil toxicants by both regulatory agencies and environmental monitoring programs [26].

Daphnia, also called "water flea", is a planktonic invertebrate organism inhabiting freshwater ecosystems. Since Daphnia are sensitive to several chemicals and easily cultured under laboratory conditions, they are considered to be very useful bioindicators in ecotoxicology [27]. The acute immobilization test [28] with daphnids is used to detect water toxicants [29,30]. Artemia spp. (brine shrimp) is a major taxon in many hypersaline biotypes throughout the world, feeding primarily on phytoplankton and being an important primary consumer [31]. They present several advantages, such as a short life cycle and adaptability to wide ranges of salinity, which have contributed to increasing the use of brine shrimps in ecotoxicological studies [31,32].

Fish are also currently used in the assessment of chemical toxicity in aquatic environments, since they are the most diverse group of vertebrates found in this ecosystem [33]. Toxicological research on fish is largely based on in vivo studies. However, today there are a number of economic, scientific and ethical reasons for supporting efforts to develop and apply in vitro assays in aquatic ecotoxicology as alternative tools to animal testing [34,35]. Fish cell lines are of particular interest since they represent standardized systems that can be carried out in a controlled environment, giving fast, affordable and ethically eligible results [34-37]. Among the fish cell lines available so far, the RTG2 cell line derived from rainbow trout (Oncorhynchus mykiss) gonadal tissue has been successfully used in assessing aquatic genotoxicants [38-43].

Considering that textile dyes are often discarded into aquatic environments and that their ecotoxicological effects are not completely known, the aim of this work was to assess the acute toxicity and genotoxicity of the textile dyes Direct Black 38 (DB38; azo dye) and Reactive Blue 15 (RB15; copper phthalocyanine dye). For this purpose, an ecotoxicity testing battery approach composed of multiple trophic levels test systems was used, since dyes, like other chemicals, can display species-specific toxicity.

\section{Material and methods}

\subsection{Tested compounds}

The dyes Direct Black 38 (DB38; Chlorazol Black E; purity $\geq 45 \%$; CAS No. 1937-37-7) and Reactive Blue 15 (RB15; Turquoise Blue; purity 35\%; CAS No.: 12225-39-7) were purchased from Sigma-Aldrich (St Louis, MO, USA). The chemical structure of each dye is presented in
Fig. 1. For all ecotoxicity assays, the dye solutions were prepared in distilled water or test medium (i.e., culture medium) used for culturing each test organism, and without addition of solvents.

\subsection{Ecotoxicity endpoints}

\subsubsection{Seed germination and root elongation toxicity test}

Lettuce (Lactuca sativa), cucumber (Cucumis sativus) and tomato (Lycopersicon esculentum) seeds were purchased from an agricultural supplies retailer. Selected species are recommended as standard species for ecotoxicological assessment by the US Environmental Protection Agency (USEPA) [44]. Prior to the test, the seeds were sterilized with ultraviolet light for $5 \mathrm{~min}$ and then rinsed several times in distilled water to prevent fungal growth. The seed germination and root elongation test on filter paper was carried out according to USEPA [44]. Ten seeds of each species were exposed on filter paper (Whatman 1) containing $3 \mathrm{~mL}$ of DB38 and RB15 at 62.5, 125, 250, 500 and $1000 \mathrm{mg} / \mathrm{L}$ in Petri dishes sealed with a plastic film. These concentrations were established after carrying out a preliminary test (range-finding test) in which the highest concentration tested, for water soluble compounds, should be the saturation concentration or $1000 \mathrm{mg} / \mathrm{L}$. The other concentrations should be chosen in a geometric series ranging from 1.5 to 2.0 [44]. Distilled water was used as the negative control (NC) and zinc sulfate heptahydrate $\left(\mathrm{ZnSO}_{4} \cdot 7 \mathrm{H}_{2} \mathrm{O} ; 3 \mathrm{mg} / \mathrm{mL}\right)$ as the positive control (PC). Three plates per concentration were prepared and incubated in complete darkness in a growth chamber at $20 \pm 1{ }^{\circ} \mathrm{C}$ for $120 \mathrm{~h}$. After this exposure period, the number of germinated seeds was counted, and the length of the root measured. The relative seed germination percentage was calculated by dividing the number of seeds germinated in the exposed groups by the number of seeds geminated in the NC. The criterion for test validation was that at least $65 \%$ of the seeds from the $\mathrm{NC}$ should germinate, and $5 \mathrm{~mm}$ of radicular protrusion was regarded as germinated.

\subsubsection{Acute toxicity test with earthworms}

E. foetida (Oligochaeta, Lumbricidae) earthworms were obtained from laboratory cultures using cow dung as the substrate and food. To void the gut contents, the earthworms were placed on moist filter paper for $3 \mathrm{~h}$ before testing. They were then washed and dried before use. Adult earthworms weighing about $300 \mathrm{mg}$ (after voiding the gut contents) with well-developed clitella were selected. The acute toxicity assay was carried out according to the Organization for Economic Cooperation and Development (OECD) Guideline 207 by the filter paper contact test [45]. The filter paper was placed on the inside wall of a tube $(3 \times 8 \mathrm{~cm})$ and $1 \mathrm{~mL}$ of DB38 or RB15 at $0.1 ; 1 ; 10 ; 100$; and $1000 \mathrm{mg} / \mathrm{L}$ then added to each tube using a micropipette, and evenly distributed over the filter paper. For this bioassay when using water soluble substances, the maximum recommended concentration tested should be $1000 \mathrm{mg} / \mathrm{L}$ [45]. The earthworms were exposed to a series of widely spaced concentrations of the dyes in order to determine the maximum effect ( $100 \%$ of mortality) at the highest concentration and no observable effect at the lowest concentration. Distilled water was used as the $\mathrm{NC}$ and $\mathrm{ZnSO}_{4} \cdot 7 \mathrm{H}_{2} \mathrm{O}(6 \mathrm{mg} / \mathrm{mL})$ as the PC. Ten replicates per concentration were made, each consisting of one adult earthworm per tube. All tubes were sealed with a plastic film with small ventilation holes and maintained at $20 \pm 2{ }^{\circ} \mathrm{C}$ and $60-80 \%$ relative humidity in the dark for $48 \mathrm{~h}$. The earthworms were considered to be dead when there was no reaction to mechanical stimulation.

\subsubsection{Daphnia magna acute immobilization test}

The acute toxicity test using $D$. magna was carried out according to OECD Guideline 202 [28] with modifications. D. magna were maintained at $20 \pm 1{ }^{\circ} \mathrm{C}$ under a $16: 8 \mathrm{~h}$ light/dark photoperiod, and fed daily with the green alga Chlorella $s p$. The experiments were carried out with 4 concentrations of DB38 and RB15 (250; 500; 750 and $1000 \mathrm{mg} /$ L) and NC (water culture). These concentrations were determined after 
(A)

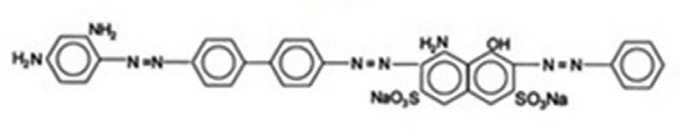

(B)

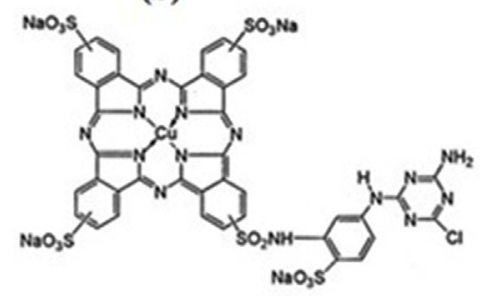

Fig. 1. The chemical structures of the Direct Black 38 (A) and Reactive Blue 15 (B) textile dyes.

a range-finding test using spaced dye concentrations. For this bioassay, the definitive test should be carried out in a geometric series with a maximum ratio of 2.2 [28]. Ten young daphnids (neonates less than 24h-old), divided into two groups of five animals each, were exposed to the DB38 or RB15 and to the controls for $48 \mathrm{~h}$ at $20 \pm 1{ }^{\circ} \mathrm{C}$ with a 16:8 h light/dark photoperiod. After $48 \mathrm{~h}$ of exposure, immobilized daphnids were counted. The test was considered valid when no more than $10 \%$ of the daphnids showed immobilization in the NC [28].

\subsubsection{Brine shrimp toxicity assay}

The brine shrimp bioassay was carried out based on the Meyer et al. [46] method and OECD Guideline 202 [28], with modifications. Brine shrimp (A. salina) nauplii were obtained by hatching dehydrated cysts in artificially prepared seawater $(3.5 \%$ commercial marine salt in deionized water) at $27 \pm 1{ }^{\circ} \mathrm{C}$, under continuous light and aeration for $48 \mathrm{~h}$. For this assay, 20 nauplii, divided into 4 groups of 5 organisms each, were exposed to $2 \mathrm{~mL}$ of DB38 (15.62, 31.25, 62.5, 125, $250 \mathrm{mg} /$ L) or RB15 $(125,250,500,750,1000 \mathrm{mg} / \mathrm{L})$. These concentrations were determined after a range-finding test using spaced dye concentrations. Artificial seawater and $10 \mathrm{mg} / \mathrm{L}$ of sodium dodecyl sulfate (SDS) were used as the NC and PC, respectively. The microplates were incubated in the dark in a climatic chamber for $48 \mathrm{~h}$ at $27 \pm 1{ }^{\circ} \mathrm{C}$. After $48 \mathrm{~h}$, completely motionless nauplii were counted as dead, and the percentage of mortality induced by the dyes as compared to that with the control, was calculated. The test was considered valid if the immobilization rate was less than $10 \%$ in the NC [28].

\subsection{Genotoxicity endpoints}

\subsubsection{In vitro comet assay using the gonad fish cell line}

RTG-2 cells (Rainbow trout gonad-2 cell line, European Collection of Authenticated Cell Cultures [ECACC] 90102529) were cultured in Leibovitz L-15 medium supplemented with $10 \%$ fetal bovine serum (FBS), 1\% L-glutamine and 1\% antibiotic (Penicillin-Streptomycin) (all from Gibco ${ }^{\circ}$ ) and maintained at $22{ }^{\circ} \mathrm{C}$ in a B.O.D. incubator. Subcultures were prepared when the cells reached $80 \%$ of confluence. RTG- 2 cells ( $5 \times 10^{4}$ cells/well, in a 24-well plate) exposed to DB38 and RB15 (32.25; 62.5; $125 ; 250 ; 500 ; 750$ and $1000 \mathrm{mg} / \mathrm{L})$ for $3 \mathrm{~h}$ were harvested and the cell pellet $(\sim 50 \mu \mathrm{L})$ re-suspended in $100 \mu \mathrm{L}$ of low melting agarose $(0.5 \% \mathrm{w} / \mathrm{v}$ in PBS). The trypan blue dye exclusion test was used to verify the cell viability and cultures with a viability equal or greater than $80 \%$ were processed for the Comet assay. The controls were prepared with L-15 medium (NC), $0.5 \mathrm{mM}$ methyl methanesulfonate (MMS) (PC of the alkaline Comet assay) and $50 \mu \mathrm{M}$ hydrogen peroxide $\left(\mathrm{H}_{2} \mathrm{O}_{2}\right.$ ) on slides and held for $10 \mathrm{~min}$ (PC of hOGG1-modified alkaline Comet assay). The cell suspension was then spread on $2 \times 1.5 \%$ agarose-coated slides, which, after solidification on ice, were immersed in a freshly prepared lysis solution $(2.5 \mathrm{M} \mathrm{NaCl} ; 100 \mathrm{mM}$ EDTA; $10 \mathrm{mM}$ Tris-HCl; $1 \%$ Lauryl sarcosinate; $1 \%$ Triton X-100 and 10\% DMSO; $\mathrm{pH}$ 10) for $2 \mathrm{~h}$. The slides were then transferred to a horizontal electrophoresis tank previously filled with electrophoresis buffer $(200 \mathrm{mM}$ EDTA; $10 \mathrm{M} \mathrm{NaOH}$; $\mathrm{pH}>13$ ) for $25 \mathrm{~min}$ at $4{ }^{\circ} \mathrm{C}$ for DNA unwinding. Electrophoresis was carried out in the same buffer for $25 \mathrm{~min}$ at $1 \mathrm{~V} / \mathrm{cm}$ and $300 \mathrm{~mA}$. The slides were neutralized with $4.85 \%$ Tris-HCl buffer (pH 7.5) for $20 \mathrm{~min}$ and dehydrated in $100 \%$ ethanol $[43,47,48]$. For the hOGG1-modified alkaline version, after lysis, the slides were washed $(3 \times$ for $5 \mathrm{~min}$ ) with enzyme buffer ( $40 \mathrm{mM}$ HEPES, $0.1 \mathrm{M} \mathrm{KCl}$, $0.5 \mathrm{Mm}$ EDTA, $0.2 \mathrm{mg} / \mathrm{mL}$ BSA, pH 8) and incubated with hOGG1 (0.08 $\mathrm{U} /$ slide, Biolabs ${ }^{\circ}$, New England) for $30 \mathrm{~min}$ at $37^{\circ} \mathrm{C}$, in a moistened chamber (manufacturer's protocol for the hOGG1 enzyme). The slides were rinsed with distilled water and placed in an electrophoresis tank for DNA unwinding and electrophoresis, as described above [43]. The slides were stained with an ethidium bromide solution $(20 \mu \mathrm{g} / \mathrm{mL}$, Sigma-Aldrich) and DNA lesions were quantified as the DNA tail intensity (\% DNA in tail) [49] by a computer-based image analysis (Metafer CometScan v.2.8.0 ${ }^{\circ}$, Metasystems, Germany) on 100 randomly selected cells.

\subsubsection{Comet assay using Daphnia magna}

The comet assay with $D$. magna was carried out based on the Olive and Banáth [50] protocol. Surviving daphnids from exposed (DB38 at 250, 500, 750 and $1000 \mathrm{mg} / \mathrm{L}$ and RB15 at 250, 500 and $750 \mathrm{mg} / \mathrm{L}$ ) and control groups (NC: water culture and PC: $10 \mu \mathrm{M} \mathrm{H}_{2} \mathrm{O}_{2}$ ) were pooled and their nuclei were isolated using mechanical disintegration with a pestle in $1 \mathrm{~mL}$ of phosphate-buffered saline (PBS) containing $20 \mathrm{mM}$ EDTA and $10 \%$ DMSO, followed by centrifugation for $5 \mathrm{~min}$ at $200 \mathrm{~g}$. The cell suspension $(\sim 30 \mu \mathrm{L})$ was embedded in $120 \mu \mathrm{L}$ of low melting agarose $(0.9 \% \mathrm{w} / \mathrm{v}$ in PBS) and spread out on slides pre-coated with normal melting agarose ( $1 \% \mathrm{w} / \mathrm{v}$ in PBS). The slides were covered with coverslips and incubated at $-20^{\circ} \mathrm{C}$ for 6 min to allow for solidification. The coverslips were removed, and the slides immersed in a freshly prepared lysis solution $(2.5 \mathrm{M} \mathrm{NaCl}, 100 \mathrm{mM}$ EDTA, $10 \mathrm{mM}$ Tris- $\mathrm{HCl}$, $1 \%$ sodium lauryl sarcosinate, $1 \%$ Triton $100-\mathrm{X}$ and $10 \%$ DMSO; $\mathrm{pH}$ 9.0) at $4{ }^{\circ} \mathrm{C}$ for $2 \mathrm{~h}$. The slides were transferred to a horizontal electrophoresis tank filled with neutral electrophoresis solution (Tris-Borate-EDTA; TBE buffer $1 \times$; $\mathrm{pH} 8.0$ ) at $4^{\circ} \mathrm{C}$ for $1 \mathrm{~h}$. Electrophoresis was carried out in the same buffer at $4^{\circ} \mathrm{C}(20 \mathrm{~V}$ and $7 \mathrm{~mA})$ for $40 \mathrm{~min}$. After electrophoresis, the slides were stained with DAPI $\left(5 \mu \mathrm{g} / \mathrm{mL} 4^{\prime}, 6\right.$-diamidino-2-phenylindole) and examined under a fluorescence microscope (Nikon E600). The DNA damage was quantified as tail intensity using the computer-based image analysis method (Comet Assay IV; Perceptive Instruments Ltd, UK) on 50 randomly selected cells from duplicate slides.

\subsection{Statistical analysis}

The GraphPad Prism (version 5.0, GraphPad Software, San Diego, CA, USA) was used for the statistical analysis of all the assays carried out. For the ecotoxicity tests and Comet assay using D. magna, comparisons between the exposed groups and their corresponding NC were carried out using a one-way variance analysis (ANOVA) followed by Dunnett's multiple comparison test and statistical significance was accepted at $\mathrm{p}<0.05$. Toxicity was expressed as the lethal $\left(\mathrm{LC}_{50}\right)$ concentration as calculated by the Probit analysis, with a $95 \%$ confidence interval. For the Comet assay using RTG2 cells, the Mann-Whitney test (non-parametric statistical test) was applied in order to verify 
differences between the exposed groups and the NC. Statistically significant $(\mathrm{p}<0.05)$ results were considered when a 2 -fold increase with respect to the NC was observed.

\section{Results and discussion}

\subsection{Acute toxicity}

\subsubsection{Phytotoxicity}

During textile processing, inefficiencies in dyeing result in large amounts of the dyestuffs being directly lost to the wastewater [3-5]. These compounds can be released into surface waters or enter terrestrial systems when sewage effluent is employed for irrigation or where sewage sludge is applied as a fertilizer to agricultural lands [26]. Thus, considering this fact, the present study investigated the ecotoxicity of two textile dyes, DB38 and RB15, on non-target organisms (terrestrial and aquatic) of different trophic levels.

The phytotoxicity of the dyes was examined using the seed germination/root elongation toxicity test with cucumber (C. sativus), lettuce (L. sativa) and tomato (L. esculentum) seeds. The plant seed germination and early seedling growth test has been considered as one of the simplest and short-term method for the study of the general toxicity of chemicals and industrial wastewaters [51]. DB38 and RB15 had no significant effect on seed germination (Fig. 2A-C) and root length (Fig. 2B-D) for any of the species tested.

Previous investigations of the effects of dyes on the environment have focused on decolorization of the textile dye wastewater [52-55], and the toxicity of their parent compounds and by-products on aquatic organisms (e.g., bioluminescent bacteria, algae, microcrustaceans and fish) $[5,7,11,56-61]$. However, there is a lack of data concerning the individual effects of textile dyes on seed germination and root elongation.

Recently, our group demonstrated that the textile azo dye Disperse
Red 343 also induced no phytotoxicity for lettuce seed (L. sativa) [62]. Gopinathan et al. [63] also observed that the basic dye Malachite Green, extensively used in textile industries, did not cause a significant effect on the seed germination and root length of mung beans (Vigna radiata), mustard (Brassica nigra) or wheat grains (Triticum aestivum) up to $100 \mathrm{mg} / \mathrm{L}$. On the other hand, Nouren et al. [64] demonstrated that the textile azo dye Direct Yellow 4 significantly affected the seed germination (50\% inhibition) and significantly reduced the root lengths of Zea mays. Taken together, the findings of these studies and ours reinforce the need of assessing dyes in their isolated form, since dyespecific toxicity can be observed (e.g., non-phytotoxicant and phytotoxicant). In addition, the hazard identification of isolated dyes can provide knowledge that might help the use of safe dyes by the textile industry, assuring the protection of the environment.

\subsubsection{Evaluation of the acute toxicity on Eisenia foetida}

As previously mentioned, the majority of the toxicological studies concerning textile dyes are carried out with aquatic organisms. However, several assays can also be carried out with terrestrial organisms in order to understand their impacts on the edaphic environment [26]. In this study, E. foetida was used as a model terrestrial organism to measure the acute toxicity of DB38 and RB15 dyes using the filter paper contact test. Earthworms are widely used to evaluate the toxic potential of soil contaminants because they are in constant contact with this ecosystem [63]. Although the importance of soil macrofauna in the balance of ecosystems and in environmental monitoring is known, few studies are available regarding the toxicity of dyes for these organisms. When exposed to contaminated environments, earthworms may alter their ecological interactions, as well as their survival and reproduction [26].

Until now, little is known about the acute toxicity of textile dyes to non-target soil organisms. In this work, DB38 and RB15 dyes did not induce lethal effects on $E$. foetida after $48 \mathrm{~h}$ of exposure, as shown in
(A)

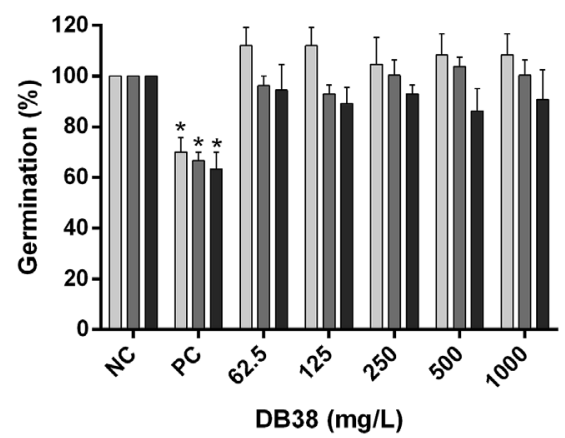

(C)

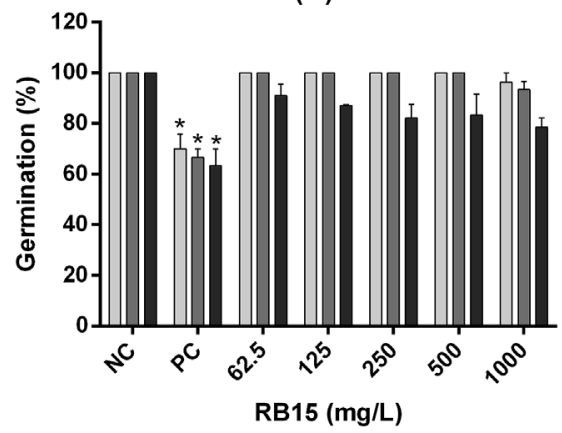

(B)

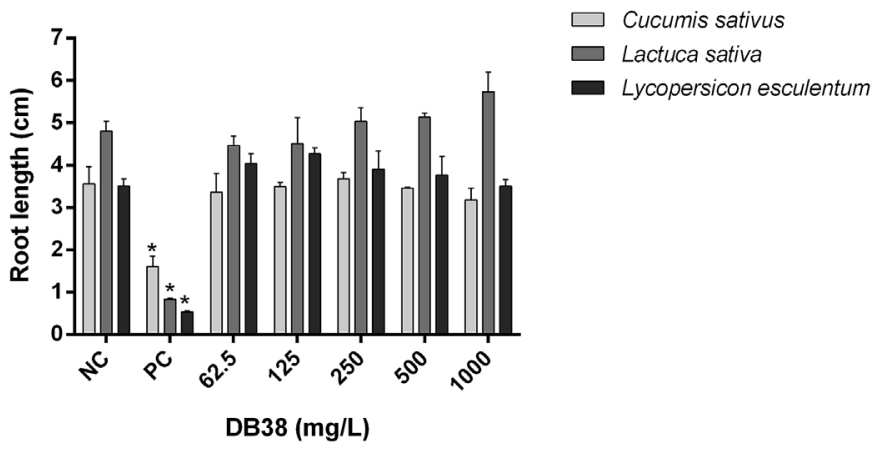

(D)

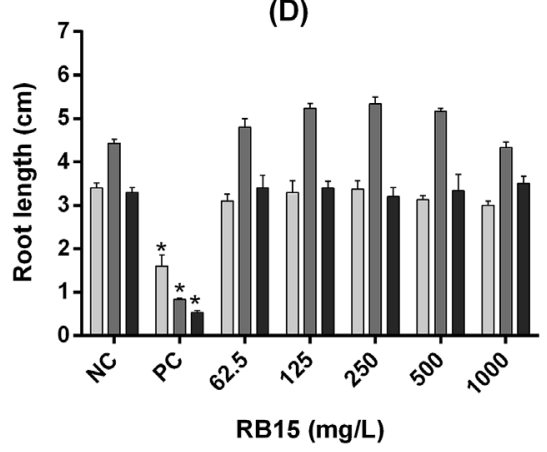

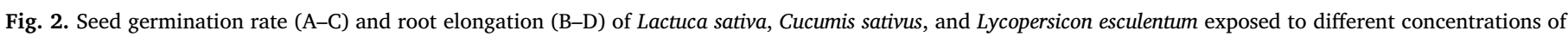

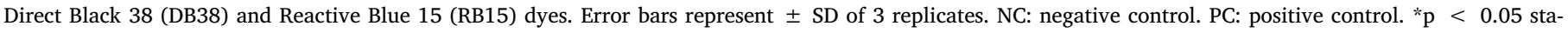
tistically different from the negative control (NC). 
Table 1

Mortality rate of Eisenia foetida after $48 \mathrm{~h}$ of exposure to Direct Black 38 and Reactive Blue 15 assessed by filter contact test $(n=10)$. NC: negative control. PC: positive control.

\begin{tabular}{llll}
\hline Concentration (mg/L) & $\begin{array}{l}\text { Direct Black 38 } \\
\text { (DB38) }\end{array}$ & $\begin{array}{l}\text { Reactive Blue 15 } \\
\text { (RB15) }\end{array}$ & Mortality (\%) \\
\hline NC & $0 / 10$ & $0 / 10$ & 0 \\
PC & $6 / 10$ & $6 / 10$ & $60^{\mathrm{a}}$ \\
0.1 & $0 / 10$ & $0 / 10$ & 0 \\
1.0 & $0 / 10$ & $0 / 10$ & 0 \\
10 & $0 / 10$ & $0 / 10$ & 0 \\
100 & $0 / 10$ & $0 / 10$ & 0 \\
1000 & $0 / 10$ & $0 / 10$ & 0 \\
\hline
\end{tabular}

a Statistically different $(\mathrm{p}<0.05)$ from the respective negative control (NC).

Table 1.

According to Pereira et al. [26], Indigo Carmin, a textile dye, only induced significant mortality of $E$. andrei after $72 \mathrm{~h}$ of exposure and at high concentrations, with a $\mathrm{LC}_{50} 72 \mathrm{~h}$ of $75.70 \mathrm{mg} / \mathrm{cm}^{2}$. As in the present study, due to the low mortality rates presented after $24 \mathrm{~h}$ and $48 \mathrm{~h}$ of exposure, it was not possible to estimate the $\mathrm{LC}_{50}$ for DB38 and RB15 dyes under the conditions tested. However, earthworms exposed to Indigo Carmine at concentrations of $1.6 \times 10^{-4}$ to $1.6 \times 10^{-2} \mathrm{mg} / \mathrm{cm}^{2}$ (lower concentrations) showed morphological alterations such as swelling and the bottleneck effect, which may indicate the total use of the reserve body energy with tissue autolysis [26]. In contrast to our results, data from the literature show that the dye Malachite Green caused severe morphological damage to $E$. foetida, but it exhibited contact toxicity with a $\mathrm{LC}_{50} 48 \mathrm{~h}$ of $2.6 \mathrm{mg} / \mathrm{cm}^{2}$.

\subsubsection{Evaluation of the acute toxicity on Daphnia magna}

The toxicity to daphnids is appropriate in order to suggest potential damage to the receptor ecosystem, and emphasizes the need for a toxicological study of the dye synthesis industry [65]. In the present work, DB38 did not induce significant mortality in D. magna. Although RB15 caused a significant lethal effect at the highest concentrations (750 mg/L and $1000 \mathrm{mg} / \mathrm{L}$ ), both dyes were classified as relatively nontoxic to $D$. magna, since their $\mathrm{LC}_{50} 48 \mathrm{~h}$ values were more than $100 \mathrm{mg}$ / $\mathrm{L}$, as shown in Table 2. However, RB15 $\left(\mathrm{LC}_{50}=686.5 \mathrm{mg} / \mathrm{L}\right)$ is about 2.5 times more toxic to daphnids than DB38 $\left(\mathrm{LC}_{50}=1698.2 \mathrm{mg} / \mathrm{L}\right)$ after $48 \mathrm{~h}$ of exposure (Table 2).

Bae and Freeman [65] also investigated the acute toxicity of direct

Table 2

Immobilization rate of Daphnia magna after $48 \mathrm{~h}$ of exposure to different concentrations of Direct Black 38 and Reactive Blue 15 dyes and their median lethal concentrations $\left(\mathrm{LC}_{50}\right)$ causing $50 \%$ of immobilization. NC: negative control.

\begin{tabular}{|c|c|c|c|c|c|}
\hline \multirow{2}{*}{$\begin{array}{l}\text { Concentration } \\
(\mathrm{mg} / \mathrm{L})\end{array}$} & \multicolumn{2}{|c|}{$\begin{array}{l}\text { Number of immobilized } \\
\text { organisms at } 48 \mathrm{~h}\end{array}$} & \multicolumn{2}{|c|}{ Immobilization } & \multirow{2}{*}{$\begin{array}{l}\mathrm{LC}_{50}(\mathrm{mg} / \mathrm{L}) \\
1698.2\end{array}$} \\
\hline & 1 & 2 & Total & $\%$ & \\
\hline NC & 0 & 0 & $0 / 10$ & 0 & \\
\hline 250 & 0 & 1 & $1 / 10$ & 10 & \\
\hline 500 & 0 & 0 & $0 / 10$ & 0 & \\
\hline 750 & 0 & 1 & $1 / 10$ & 10 & \\
\hline 1000 & 1 & 2 & $3 / 10$ & 30 & \\
\hline Reactive Blue 15 & & & & & 686.5 \\
\hline NC & 0 & 0 & $0 / 10$ & 0 & \\
\hline 250 & 0 & 0 & $0 / 10$ & 0 & \\
\hline 500 & 2 & 1 & $3 / 10$ & 30 & \\
\hline 750 & 3 & 2 & $5 / 10$ & $50 *$ & \\
\hline 1000 & 4 & 5 & $9 / 10$ & $90 *$ & \\
\hline
\end{tabular}

*Statistically different $(\mathrm{p}<0.05)$ from the respective negative control (NC).
Table 3

Immobilization rate of Artemia salina after $48 \mathrm{~h}$ of exposure to different concentrations of Direct Black 38 and Reactive Blue 15 dyes and their median lethal concentrations $\left(\mathrm{LC}_{50}\right)$ causing $50 \%$ of immobilization. NC: negative control. PC: positive control.

\begin{tabular}{|c|c|c|c|c|c|c|c|}
\hline \multirow{2}{*}{$\begin{array}{l}\text { Concentration } \\
(\mathrm{mg} / \mathrm{L})\end{array}$} & \multicolumn{4}{|c|}{$\begin{array}{l}\text { Number of immobilized } \\
\text { organisms at } 48 \mathrm{~h}\end{array}$} & \multicolumn{2}{|c|}{ Immobilization } & \multirow{2}{*}{$\begin{array}{l}\mathrm{LC}_{50}(\mathrm{mg} / \\
\mathrm{L}) \\
20.7\end{array}$} \\
\hline & 1 & 2 & 3 & 4 & Total & $\%$ & \\
\hline NC & 0 & 0 & 1 & 1 & $2 / 20$ & 10 & \\
\hline PC & 2 & 3 & 3 & 2 & $10 / 20$ & $50 *$ & \\
\hline 15.62 & 2 & 2 & 2 & 1 & $7 / 20$ & 35 & \\
\hline 31.25 & 4 & 2 & 3 & 3 & $12 / 20$ & $60 *$ & \\
\hline 62.5 & 5 & 5 & 4 & 5 & $19 / 20$ & $95^{*}$ & \\
\hline 125.0 & 5 & 5 & 5 & 5 & $20 / 20$ & $100 *$ & \\
\hline 250.0 & 5 & 5 & 5 & 5 & $20 / 20$ & $100 *$ & \\
\hline Reactive Blue 15 & 1 & 2 & 3 & 4 & Total & $\%$ & 1313.0 \\
\hline NC & 0 & 1 & 0 & 1 & $2 / 20$ & 10 & \\
\hline PC & 2 & 3 & 3 & 2 & $10 / 20$ & $50 *$ & \\
\hline 125.0 & 1 & 0 & 1 & 1 & $3 / 20$ & 15 & \\
\hline 250.0 & 2 & 1 & 0 & 1 & $4 / 20$ & 20 & \\
\hline 500.0 & 1 & 1 & 2 & 0 & $4 / 20$ & 20 & \\
\hline 750.0 & 2 & 1 & 2 & 2 & $7 / 20$ & 35 & \\
\hline 1000.0 & 2 & 3 & 3 & 2 & $10 / 20$ & $50 *$ & \\
\hline
\end{tabular}

*Statistically different $(\mathrm{p}<0.05)$ from the respective negative control (NC).

azo dyes: Direct Blue 218 and four new non-genotoxic direct dyes based on benzidine congeners, 2,2'-dimethyl-5,5'-dipropoxybenzidine and 5,5'-dipropoxybenzidine, using D. magna. In this study, Direct Blue 218 was toxic to this organism with a $\mathrm{LC}_{50} 48 \mathrm{~h}$ between 1.0 and $10.0 \mathrm{mg} / \mathrm{L}$, while four new non-genotoxic direct dyes were relatively non-toxic to daphnids, with a $\mathrm{LC}_{50} 48 \mathrm{~h}$ of more than $100 \mathrm{mg} / \mathrm{L}$. The authors emphasized that Direct Blue 218 has two copper molecules in its structure, while the four new direct dyes have no metal in their structures. Thus they suggested that copper molecules could have an important role in the toxicity of the Direct Blue 218 dye. According to Traudt et al. [66], copper is very toxic to $D$. magna with $\mathrm{LC}_{50} 48 \mathrm{~h}$ of $0.1 \mathrm{mg} / \mathrm{L}$. This fact could also justify the higher toxicity of RB15 as compared to DB38, since RB15 is a copper phthalocyanine dye, which has one copper molecule in its structure.

\subsubsection{Evaluation of the acute toxicity on brine shrimp}

In order to understand the impacts of textile dyes on marine ecosystems, the acute toxicity of DB38 and RB15 to A. salina was evaluated. Table 3 shows the percent mortality (immobility) of $A$. salina nauplii after $48 \mathrm{~h}$ of exposure to different concentrations of the DB38 and RB15 dyes. Both dyes induced significant toxicity to $A$. salina nauplii in a concentration-dependent way. However, DB38 $\left(\mathrm{LC}_{50} 48 \mathrm{~h}=20.7 \mathrm{mg}\right.$ / L) was more toxic than RB15, which presented a $\mathrm{LC}_{50} 48 \mathrm{~h}$ of $1313 \mathrm{mg} /$ L. According to the general concept of aquatic toxicity [65], DB38 was moderately toxic to A. salina whereas RB15 was relatively non-toxic to this organism.

As previously discussed, the toxicity of textile dyes can be speciesspecific. According to Leme et al. [4], the azo dye Reactive Red 120 was moderately toxic to $A$. salina with a $\mathrm{LC}_{50} 48 \mathrm{~h}$ of $81.89 \mathrm{mg} / \mathrm{L}(10 \mathrm{mg} /$ $\mathrm{L}<\mathrm{LC}_{50}<100 \mathrm{mg} / \mathrm{L}$ ) and relatively non-toxic to $D$. similis with a $\mathrm{LC}_{50} 48 \mathrm{~h}$ of $172.36 \mathrm{mg} / \mathrm{L}\left(\mathrm{LC}_{50}>100 \mathrm{mg} / \mathrm{L}\right)$. Considering that the $\mathrm{LC}_{50} 48 \mathrm{~h}$ of copper for another specie of saline microcrustacean, $A$. franciscana, is quite high $(12,000 \mathrm{mg} / \mathrm{L})$, the presence of this metal did not interfere in the acute toxicity of RB15 on A. salina [67].

Although lethal concentrations ( $\mathrm{LC}_{50} 48 \mathrm{~h}$ ) greater than $100 \mathrm{mg} / \mathrm{L}$ are considered relatively non-toxic for aquatic organisms, indicating a low hazard for the aquatic environment, about $50 \%$ of the reactive dyes remain in the dye bath during the dye fixation step on the fibers, and an average of $300 \mathrm{mg} / \mathrm{L}$ of dye has been detected in effluents from textile manufacturing processes $[6,9,68]$. 
(A)

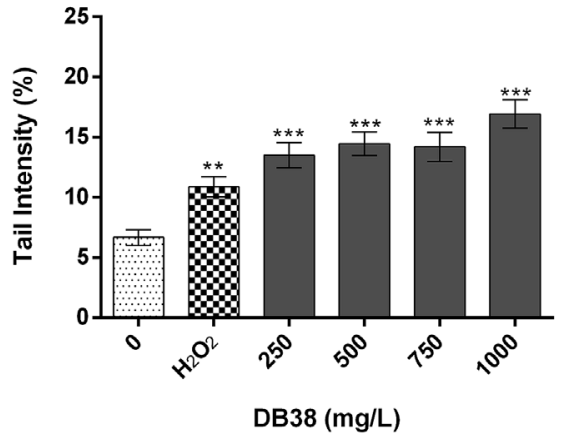

(B)

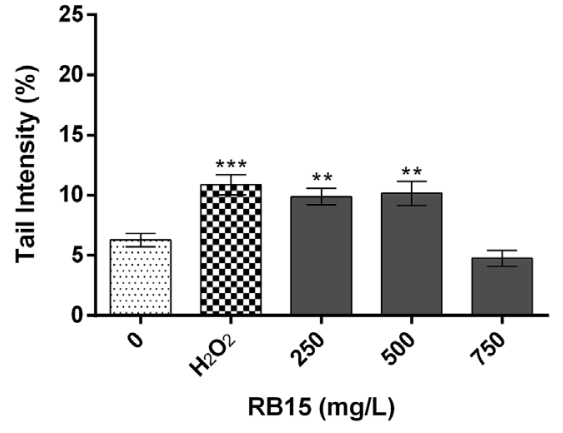

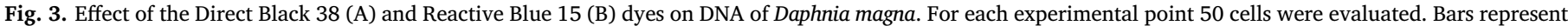
mean \pm SEM of individual cells. ${ }^{* *} \mathrm{p}<0.001$ and ${ }^{* *} \mathrm{p}<0.05$ statistically different from the negative control (NC).

\subsection{Genotoxicity}

The relevance of detecting the genotoxic hazard/risk associated with water pollution arose as from the late 1970s. Since that time, the analysis of DNA alterations in aquatic organisms has been shown to be a highly suitable approach for evaluating the genotoxic hazard of aquatic environments [69]. Thus we assessed the genotoxic potential of DB38 and RB15 using daphnids and in vitro fish cells (RTG-2) as models of aquatic organisms.

The DNA damage of $D$. magna induced by the DB38 and RB15 dyes was assessed using the neutral Comet assay. This Comet assay version is carried out under neutral conditions and allows for the detection of DNA double-strand breaks (DSBs) [50]. Fig. 3 shows that the DB38 and RB15 dyes induced significant damage in the DNA of the $D$. magna as from $250 \mathrm{mg} / \mathrm{L}$, after $48 \mathrm{~h}$ of exposure. RB15 at $750 \mathrm{mg} / \mathrm{L}$ did not induce significant DNA DSBs, probably due to the high number of daphnids dead after exposure.

With respect to the effects on fish, increased levels of DNA fragments were not observed in RB15-exposed RTG- 2 cells in any of the Comet assay versions carried out (Fig. 4). To the contrary, DB38 was able to increase the DNA fragments in RTG-2 cells, acting as a direct (DNA strand breaks) and indirect (oxidized bases) genotoxicant, but only at the lowest concentrations tested (increasing concentration-dependence from 32.25 to $125 \mu \mathrm{g} / \mathrm{mL}$, significant at $125 \mu \mathrm{g} / \mathrm{mL}$ ) (Fig. 4). Moreover, the genotoxic mode of action (MoA) prevailing was oxidative DNA damage, since greater increases in DNA strand breaks $(3.35 \times)$ were verified for the hOGG1-modified alkaline version as compared to the standard Comet assay (alkaline) $(2.45 \times)$ at $125 \mu \mathrm{g} / \mathrm{mL}$ (significant value) (Fig. 4).

Opposite biological effects of a stressor at low and high doses, showing a biphasic dose-response relationship (inverted U- or J-shaped curves), may represent hormesis [70]. Hormetic dose-response in Genetic Toxicology is usually reported as J-shaped curves, wherein mutation rates at low doses are less than the spontaneous level, whereas high doses display mutagenicity [71,72].

Despite the fact that hormesis is usually reported as a J-shaped response in Genetic Toxicology, the genotoxicity of DB38 at the lower concentrations, followed by the inhibition of this effect at the highest concentrations tested (inverted U-shaped curve), also fits the concept of hormesis. In addition, another feature that reinforces the occurrence of a genotoxic hormetic dose-response for DB38 is the magnitude of the response. Usually, hormetic dose response relationships cause a modest stimulatory response, typically around twofold as compared to the control [70,73,74]. RTG-2 cells exposed to DB38 showed increasing genotoxic effects of from 32.25 to $125 \mu \mathrm{g} / \mathrm{mL}, 2.46$ - and 3.35-fold higher than the control at $125 \mu \mathrm{g} / \mathrm{mL}$ (significant value), for the standard and oxidative Comet assays, respectively.

The hormetic genotoxic response observed for DB38 may be related to the 'starting point' required for triggering defense mechanisms (e.g., DNA repair) in the exposed biological system. Fish possess low/slow overall DNA repair capacity as compared to mammals [75,76]. Walton and co-authors [77] showed that fish cell lines, including rainbow trout gonad cells, have a significantly lower magnitude of DNA repair synthesis than mammalian cells, which usually show pronounced doseresponses of DNA repair activities as from low concentrations.

DB38 has also been investigated by the present research group regarding its capacity for inducing DNA damage in humans. Genotoxicity was not verified for DB38 when assessed by the in vitro Comet assay with dermal human fibroblast (primary cells) [72], studying the hormetic genotoxic response of $N$-methyl- $N$-nitrosourea (MNU) in two human lymphoblastoid cell lines (TK6 and NH32), showed that hormesis is unlikely to be generalized across different cell types, due to differences in the cell cycle control (e.g. p53 functional status) and in the DNA repair capacities.

Hence these facts lead the authors to hypothesize that the genotoxic effects of DB38 at the lower concentrations were due to the absence of a pronounced DNA repair activity, which only started to be effective at the higher concentrations, where no genotoxicity was verified. However, whether the DNA repair capacity of the RTG-2 cells is responsible or otherwise for hormesis-like genotoxicity should be further explored.

\section{Conclusions}

Taken together, the present findings showed that the DB38 and RB15 dyes caused acute toxicity and genotoxicity for aquatic organisms, but caused no concerns with respect to terrestrial ecosystems, since phytotoxicity and earthworm toxicity were not observed. DB38 was the most toxic dye, due to its lethal toxicity on A. salina and capacity to induce DNA damage in D. magna and RTG-2 cells. In addition, the authors attempted to carry out ecotoxicity testing within the concentration ranges of the dyes closer to those found in the environment, due to their potential to induce hormesis effects (i.e., adverse effects at low concentrations). Therefore the results emphasize that a test battery approach of bioassays representing multiple trophic levels is fundamental to predict the toxicity of textile dyes, in addition to providing the knowledge required to define the safe levels of textile dyes for terrestrial and aquatic environments.

\section{Conflicts of interest}

The authors declare there are no conflicting interests.

\section{Acknowledgment}

The authors are grateful to the São Paulo Research Foundation 
Reactive Blue 15

Alkaline version

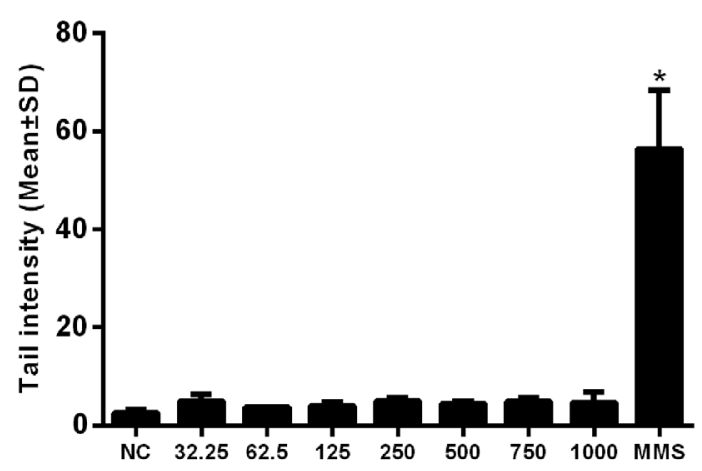

Direct Black 38

Alkaline version

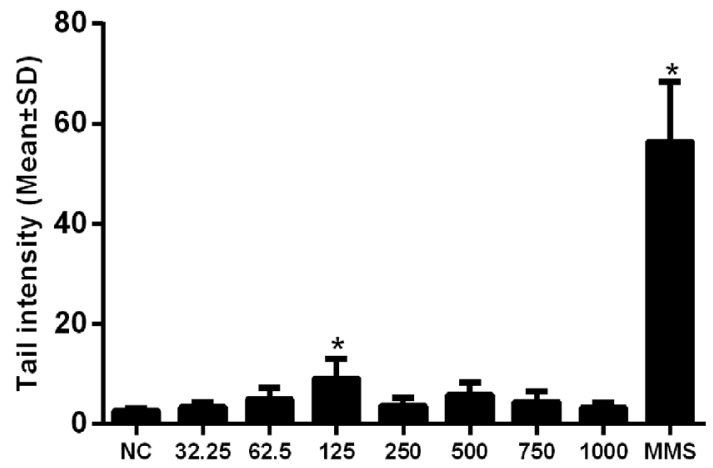

Reactive Blue 15

hOGG1-modified alkaline version

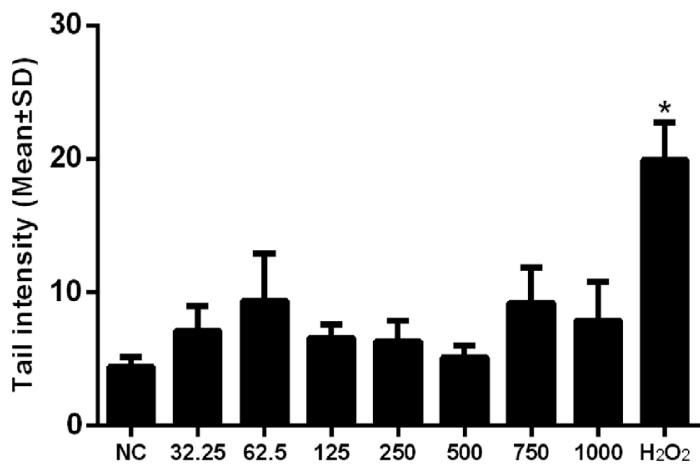

Direct Black 38

hOGG1-modified alkaline version

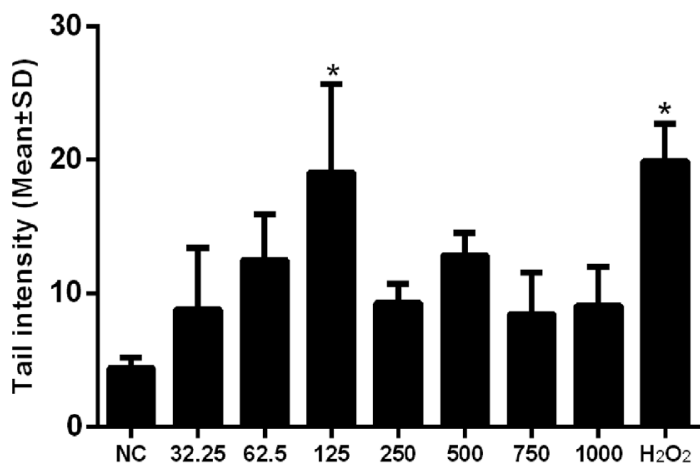

Fig. 4. DNA damages induced by the textile dyes Reactive Blue 15 (RB15) and Direct Black 38 (DB38) in gonadal fish cell line (RTG-2). Data expressed as mean \pm standard deviation (SD) of $\%$ of DNA in tail (Tail Intensity) and dyes' concentrations at $\mu \mathrm{g} / \mathrm{mL}$. NC: negative control; MMS: Methyl methanesulfonate at $0.5 \mathrm{mM}$ (positive control of alkaline version); $\mathrm{H}_{2} \mathrm{O}_{2}$ : hydrogen peroxide at $50 \mu \mathrm{M}$ (positive control of hOGG1-modified alkaline version). *indicates the statistical difference, $\mathrm{p}<0.05$, and a $>2$-fold change DNA damage related to NC.

(FAPESP - Process No. 2010/01487-2), the Goiás Research Foundation (FAPEG), the Araucária Foundation, and to the National Council for Scientific and Technological Development (CNPq: INCT/DATREM Process No. 465571/2014-0), for their financial support and scholarships. The authors would like also to thank the School of Pharmaceutical Sciences of Ribeirão Preto, University of São Paulo; the Unit of Experimental Toxicology and Ecotoxicology, Barcelona Science Park; the Multi-User Confocal Microscopy Center of the Federal University of Paraná; and the Faculty of Pharmacy, Federal University of Goiás for their help in carrying out this research.

\section{Transparency document}

Transparency document related to this article can be found online at http://dx.doi.org/10.1016/j.cbi.2018.06.026.

\section{References}

[1] D.P. Oliveira, P.A. Carneiro, C.M. Rech, M.V.B. Zanoni, L.D. Claxton, G.A. Umbuzeiro, Mutagenic compounds generated from the chlorination of disperse azo-dyes and their presence in drinking water, Environ. Sci. Technol. 40 (2006) 6682-6689, http://dx.doi.org/10.1021/es061020p.

[2] E.R.A. Ferraz, G.A. Umbuzeiro, G. de-Almeida, A. Caloto-Oliveira, F.M.D. Chequer, M.V.B. Zanoni, D.J. Dorta, D.P. Oliveira, Differential toxicity of disperse red 1 and disperse red 13 in the ames test, HepG2 cytotoxicity assay, and Daphnia acute toxicity test, Environ. Toxicol. 26 (2010) 489-497, http://dx.doi.org/10.1002/tox. 20576.

[3] E.R.A. Ferraz, G.A.R. Oliveira, M.D. Grando, T.M. Lizier, M.V.B. Zanoni, D.P. Oliveira, Photoelectrocatalysis based on $\mathrm{Ti} / \mathrm{TiO} 2$ nanotubes removes toxic properties of the azo dyes Disperse Red 1, Disperse Red 13 and Disperse Orange from aqueous chloride samples, J. Environ. Manag. 124 (2013) 108-114, http://dx. doi.org/10.1016/j.jenvman.2013.03.033.

[4] D.M. Leme, G.A.R. Oliveira, G. Meireles, L.B. Brito, L.B. Rodrigues, D.P. Oliveira, Eco- and genotoxicological assessments of two reactive textile dyes, J. Toxicol. Environ. Health 78 (2015) 287-300, http://dx.doi.org/10.1080/15287394.2014. 971208.

[5] G.A.R. Oliveira, J. Lapuente, E. Teixidó, C. Porredó, M. Borràs, D.P. Oliveira, Textile dyes induce toxicity on zebrafish early life stages, Environ. Toxicol. Chem. 35 (2016) 429-434, http://dx.doi.org/10.1002/etc.3202.

[6] F.I. Vacchi, P.C.V. Ohe, A.F. Albuquerque, J.A.S. Vendemiatti, C.C.J. Azevedo, J.G. Honório, B.F. Silva, M.V.B. Zanoni, T.B. Henry, A.J. Nogueira, G.A. Umbuzeiro, Occurrence and risk assessment of an azo dye - the case of Disperse Red 1, Chemosphere 156 (2016) 95-100, http://dx.doi.org/10.1016/j.chemosphere.2016. 04.121.

[7] F.I. Vacchi, J.A.S. Vendemiatti, B.F. Silva, M.V.B. Zanoni, G.A. Umbuzeiro, Quantifying the contribution of dyes to the mutagenicity of waters under the influence of textile activities, Sci. Total Environ. 601-602 (2017) 230-236, http://dx. doi.org/10.1016/j.scitotenv.2017.05.103.

[8] A.A. Gurav, J.K. Ghosh, G.S. Kulkarni, Decolorization of anthroquinone based dye Vat Red 10 by Pseudomonas desmolyticum NCIM 2112 and Galactomyces geotrichum MTCC 1360, Int. J. Biotechnol. Mol. Biol. Res. 2 (2011) 93-97.

[9] G.A. Oliveira, E.R. Ferraz, F.M. Chequer, M.D. Grando, J.P. Angeli, M.S. Tsuboy, J.C. Marcarini, M.S. Mantovani, M.E. Osugi, T.M. Lizier, M.V. Zanoni, D.P. Oliveira Chlorination treatment of aqueous samples reduces, but does not eliminate, the mutagenic effect of the azo dyes Disperse Red 1, Disperse Red 13 and Disperse Orange 1, Mutat. Res. 703 (2010) 200-208, http://dx.doi.org/10.1016/j.mrgentox. 
2010.09.001.

[10] E.R. Ferraz, Z. Li, O. Boubriak, D.P. Oliveira, Hepatotoxicity assessment of the azo dyes disperse orange 1 (DO1), disperse red 1 (DR1) and disperse red 13 (DR13) in HEPG2 cells, J. Toxicol. Environ. Health 75 (2012) 991-999, http://dx.doi.org/10. 1080/15287394.2012.696513.

[11] E.R.A. Ferraz, M.D. Grando, D.P. Oliveira, The azo dye Disperse Orange 1 induces DNA damage and cytotoxic effects but does not cause ecotoxic effects in Daphnia similis and Vibrio fischeri, J. Hazard Mater. 192 (2011) 628-633, http://dx.doi. org/10.1016/j.jhazmat.2011.05.063.

[12] D.M. Leme, F.L. Primo, G.G. Gobo, C.R. Costa, A.C. Tedesco, D.P. Oliveira, Genotoxicity assessment of reactive and disperse textile dyes using human dermal equivalent (3D cell culture system), J. Toxicol. Environ. Health 78 (2015) 466-480, http://dx.doi.org/10.1080/15287394.2014.999296.

[13] F.R. Abe, A.M.V.M. Soares, D.P. Oliveira, C. Gravato, Toxicity of dyes to zebrafish at the biochemical level: cellular energy allocation and neurotoxicity, Environ. Pollut. 235 (2018) 255-262, http://dx.doi.org/10.1016/j.envpol.2017.12.020.

[14] R. Croce, F. Cinà, A. Lombardo, G. Crispeyn, C.I. Cappelli, M. Vian, S. Maiorana, E. Benfenati, D. Baderna, Aquatic toxicity of several textile dye formulations: acute and chronic assays with Daphnia magna and Raphidocelis subcapitata, Ecotoxicol. Environ. Saf. 144 (2017) 79-87, http://dx.doi.org/10.1016/j.ecoenv.2017.05.046.

[15] D.M. Leme, A. Sehr, T. Grummt, J.P. Gonçalves, T. Jacomasso, S.M.B. Winnischofer, F.B. Potrich, C.C. Oliveira, E.D.S. Trindade, D.P. de Oliveira, In vitro characterization of cutaneous immunotoxicity of immortalized human keratinocytes (HaCaT) exposed to reactive and disperse textile dyes, J. Toxicol. Environ. Health 1 (2018) 1-15, http://dx.doi.org/10.1080/15287394.2018.1464981.

[16] International Agency for Research on Cancer, Direct Black 38, IARC Monogr eval carcinog risk, Chem. Hum 29 (1982) 295-310.

[17] National Toxicology Program, Benzidine and Dyes Metabolized to Benzidine: Dyes Metabolized to Benzidine (Benzidine Dye Class), Report on Carcinogens, twelfth ed., US Department of Health and Human Services, Washington, DC, 2011, pp. 64-66.

[18] N. Mathur, P. Bhatnagar, P. Bakre, Assessing mutagenicity of textile dyes from Pali (Rajasthan) using Ames bioassay, Appl. Ecol. Environ. Res. 4 (2005) 111-118.

[19] P. Rajaguru, R. Kalpana, A. Hema, S. Suba, B. Baskarasethupathi, P.A. Kumar, K. Kalaiselvi, Genotoxicity of some sulfur dyes on tadpoles (Rana hexadactyla) measured using the comet assay, Environ. Mol. Mutagen. 38 (2001) 316-322, http://dx.doi.org/10.1002/em.10027.

[20] M.E. Osugi, G.A. Umbuzeiro, F.J. De Castro, M.V. Zanoni, Photoelectrocatalytic oxidation of remazol turquoise blue and toxicological assessment of its oxidation products, J. Hazard Mater. 137 (2006) 871-877, http://dx.doi.org/10.1016/j. jhazmat.2006.03.036.

[21] R.E. Connon, J. Geist, I. Werner, Effect-based tools for monitoring and predicting the ecotoxicological effects of chemicals in the aquatic environment, Sensors 12 (2012) 12741-12771, http://dx.doi.org/10.3390/s120912741.

[22] C. Boutin, B. Strandberg, D. Carpenter, S.K. Mathiassen, P.J. Thomas, Herbicide impact on non-target plant reproduction: what are the toxicological and ecological implications? Environ. Pollut. 185 (2014) 295-306, http://dx.doi.org/10.1016/j. envpol.2013.10.009.

[23] J. Lyu, J. Park, L.K. Pandey, S. Choi, H. Lee, J. De Saeger, S. Depuydt, T. Han, Testing the toxicity of metals, phenol, effluents, and receiving waters by root elongation in Lactuca sativa L, Ecotoxicol. Environ. Saf. 149 (2018) 225-232, http://dx.doi.org/10.1016/j.ecoenv.2017.11.006.

[24] M.R. Pino, J. Val, A.M. Mainar, E. Zuriaga, C. Español, E. Langa, Acute toxicological effects on the earthworm Eisenia fetida of 18 common pharmaceuticals in artificial soil, Sci. Total Environ. 518-519 (2015) 225-237, http://dx.doi.org/10.1016/j. scitotenv.2015.02.080

[25] G. Yang, C. Chen, Y. Wang, Q. Peng, H. Zhao, D. Guo, Q. Wang, Y. Qian, Mixture toxicity of four commonly used pesticides at different effect levels to the epigeic earthworm, Eisenia fetida, Ecotoxicol. Environ. Saf. 142 (2017) 29-39, http://dx doi.org/10.1016/j.ecoenv.2017.03.037.

[26] P.C.G. Pereira, R.V. Reimão, T. Pavesi, E.M. Saggioro, J.C. Moreira, F.V. Correia, Lethal and sub-lethal evaluation of Indigo Carmine dye and byproducts after $\mathrm{TiO}_{2}$ photocatalysis in the immune system of Eisenia andrei earthworms, Ecotoxicol. Environ. Saf. 143 (2017) 275-282, http://dx.doi.org/10.1016/j.ecoenv.2017.05. 043.

[27] A. Bownik, Daphnia swimming behaviour as a biomarker in toxicity assessment: a review, Sci. Total Environ. 601-602 (2017) 194-205, http://dx.doi.org/10.1016/j. scitotenv.2017.05.199.

[28] OECD, Test No. 202: Daphnia Sp. Acute Immobilisation Test, OECD Publishing, 2004

[29] J. Martins, O. Teles, V. Vasconcelos, Assays with Daphnia magna and Danio rerio as alert systems in aquatic toxicology, Environ. Int. 33 (2007) 414-425, http://dx.doi. org/10.1016/j.envint.2006.12.006.

[30] P. Ghosh, I.S. Thakur, A. Kaushik, Bioassays for toxicological risk assessment of landfill leachate: a review, Ecotoxicol. Environ. Saf. 141 (2017) 259-270, http://dx doi.org/10.1016/j.ecoenv.2017.03.023.

[31] G. Libralato, E. Prato, L. Migliore, A.M. Cicero, L. Manfra, A review of toxicity testing protocols and endpoints with Artemia spp, Ecol. Indicat. 69 (2016) 35-49, http://dx.doi.org/10.1016/j.ecolind.2016.04.017.

[32] B.S. Nunes, F.D. Carvalho, L.M. Guilhermino, G.B. Stappen, Use of the genus Artemia in ecotoxicity testing, Environ. Pollut. 144 (2006) 453-462, http://dx.doi. org/10.1016/j.envpol.2005.12.037.

[33] N.C. Bols, V.R. Dayeh, L.E.J. Lee, K. Schirmer, Chapter 2 Use of fish cell lines in the toxicology and ecotoxicology of fish. Piscine cell lines in environmental toxicology, Biochem. Mol. Biol. Fishes 6 (2005) 43-84, http://dx.doi.org/10.1016/S18730140(05)80005-0.
[34] A. Castaño, N. Bols, T. Braunbeck, P. Dierickx, M. Halder, B. Isomaa, K. Kawahara L.E.J. Lee, C. Mothersill, P. Pärt, G. Repetto, J.R. Sintes, H. Rufli, R. Smith, C. Wood, H.S. Castaño, The use of fish cells in ecotoxicology, Altern. Lab. Anim 31 (2003) 317-351

[35] P. Pannetier, L. Fuster, C. Clérandeau, C. Lacroix, P.Y. Gourves, J. Cachot, B. Morin Usefulness of RTL-W1 and OLCAB-e3 fish cell lines and multiple endpoint measurements for toxicity evaluation of unknown or complex mixture of chemicals, Ecotoxicol. Environ. Saf. 150 (2018) 40-48, http://dx.doi.org/10.1016/j.ecoenv. 2017.12.027.

[36] A. Kienzler, S. Bony, X. Tronchère, A. Devaux, Assessment of base-excision repair activity in fish cell lines: toward a new biomarker of exposure to environmental contaminants? Mutat. Res. Genet. Toxicol. Environ. Mutagen 753 (2013) 107-113, http://dx.doi.org/10.1016/j.mrgentox.2013.03.004.

[37] A. Lillicrap, S. Belanger, N. Burden, D.D. Pasquier, M.R. Embry, M. Halder, M.A. Lampi, L. Lee, T. Norberg-King, B.A. Rattner, K. Schirmer, P. Thomas, Alternative approaches to vertebrate ecotoxicity tests in the 21st century: a review of developments over the last 2 decades and current status, Environ. Toxicol. Chem. 35 (2016) 2637-2646, http://dx.doi.org/10.1002/etc.3603.

[38] S. Nehls, H. Segner, Detection of DNA damage in two cell lines from rainbow trout, RTG-2 and RTL-W1, using the comet assay, Environ. Toxicol 16 (2001) 321-329, http://dx.doi.org/10.1002/Tox.1039.

[39] S. Raisuddin, A.N. Jha, Relative sensitivity of fish and mammalian cells to sodium arsenate and arsenite as determined by alkaline single-cell gel electrophoresis an cytokinesis-block micronucleus assay, Environ. Mol. Mutagen. 44 (2004) 83-89, http://dx.doi.org/10.1002/em.20027.

[40] S. Nehls, H. Segner, Comet assay with the fish cell line rainbow trout gonad-2 for in vitro genotoxicity testing of xenobiotics and surface waters, Environ. Toxicol. Chem. 24 (2005) 2078-2087, http://dx.doi.org/10.1897/04-301R.1.

[41] E. Papis, S.J. Davies, A.N. Jha, Relative sensitivity of fish and mammalian cells to the antibiotic, trimethoprim: cytotoxic and genotoxic responses as determined by neutral red retention, Comet and micronucleus assays, Ecotoxicology 20 (2011) 208-217, http://dx.doi.org/10.1007/s10646-010-0572-2.

[42] M. Munari, J. Sturve, G. Frenzilli, M.B. Sanders, A. Brunelli, A. Marcomini, M. Nigro, B.P. Lyons, Genotoxic effects of CdS quantum dots and $\mathrm{Ag}_{2} \mathrm{~S}$ nanoparticle in fish cell lines (RTG-2), Mutat. Res. Genet. Toxicol. Environ. Mutagen. 775-776 (2014) 89-93, http://dx.doi.org/10.1016/j.mrgentox.2014.09.003.

[43] I. Felzenszwalb, A.S. Fernandes, L.B. Brito, G.A.R. Oliveira, P.A.S. Silva, M.E. Arcanjo, M.R.C. Marques, T. Vicari, D.M. Leme, M.M. Cestari, E.R.A. Ferraz, Toxicological evaluation of nail polish waste discarded in the environment, Environ. Sci. Pollut. Res. Int. (2018), http://dx.doi.org/10.1007/s11356-0181880-y.

[44] US Environmental Protection Agency (USEPA), Seed Germination/root Elongation Toxicity Test, OPPTS 850.4200, EPA 712/C-96/154. Ecological Effects Test Guidelines. Washington, DC, (1996).

[45] OECD, Test No, 207: Earthworm, Acute Toxicity Tests, OECD Publishing, 1984.

[46] B.N. Meyer, N.R. Ferrigni, J.E. Putnan, L.B. Jacobsen, D.E. Nichols, J. McLaughlin, Brine shrimp: a convenient general bioassay for active plant constituents, J. Med. Plants Res. 45 (1982) 31-34.

[47] R.R. Tice, E. Agurell, D. Anderson, B. Burlinson, A. Hartmann, H. Kobayashi, Y. Miyamae, E. Rojas, J.C. Ryu, Y.F. Sasaki, Single cell gel/comet assay: guidelines for in vitro and in vivo genetic toxicology testing, Environ. Mol. Mutagen. 35 (2000) 206-221, http://dx.doi.org/10.1002/(SICI)1098-2280(2000)35:3<206:AIDEM8 > 3.0.CO;2-J.

[48] D.M. Leme, G.A. Oliveira, G. Meireles, T.C. Santos, M.V. Zanoni, D.P. Oliveira, Genotoxicological assessment of two reactive dyes extracted from cotton fibres using artificial sweat, Toxicol. Vitro 28 (2014) 31-38, http://dx.doi.org/10.1016/j. tiv.2013.06.005.

[49] T.S. Kumaravel, B. Vilhar, S.P. Faux, A.N. Jha, Comet Assay measurements: a perspective, Cell Biol. Toxicol. 25 (2009) 53-64, http://dx.doi.org/10.1007/s10565007-9043-9.

[50] P.L. Olive, J.P. Banáth, The comet assay: a method to measure DNA damage in individual cells, Nat. Protoc. 1 (2006) 23-29, http://dx.doi.org/10.1038/nprot. 2006.5.

[51] I. Haq, A. Raj, Markandey, Biodegradation of Azure-B dye by Serratia liquefaciens and its validation by phytotoxicity, genotoxicity and cytotoxicity studies, Chemosphere 196 (2018) 58-68, http://dx.doi.org/10.1016/j.chemosphere.2017. 12.153.

[52] M. Isik, D.T. Sponza, Monitoring of toxicity and intermediates of C.I. Direct Black 38 azo dye through decolorization in an anaerobic/aerobic sequential reactor system, J. Hazard Mater. 114 (2004) 29-39, http://dx.doi.org/10.1016/j.jhazmat. 2004.06.011.

[53] C.T. Frijters, R.H. Vos, G. Scheffer, R. Mulder, Decolorizing and detoxifying textile wastewater, containing both soluble and insoluble dyes, in a full scale combined anaerobic/aerobic system, Water Res. 40 (2006) 1249-1257, http://dx.doi.org/10. 1016/j.watres.2006.01.013.

[54] V.M. Grinevicius, R. Geremias, R. Laus, K.F. Bettega, M.C. Laranjeiras, V.T. Fávere D. Wilhelm Filho, R.C. Pedrosa, 2009. Textile effluents induce biomarkers of acute toxicity, oxidative stress, and genotoxicity, Arch. Environ. Contam. Toxicol. 57 (2009) 307-314, http://dx.doi.org/10.1007/s00244-008-9263-x.

[55] O. Benzina, D. Daâssi, H. Zouari-Mechichi, F. Frikha, S. Woodward, L. Belbahri, S. Rodriguez-Couto, T. Mechichi, Decolorization and detoxification of two textile industry effluents by the laccase/1-hydroxybenzotriazole system, Environ. Sci. Pollut. Res. 20 (2013) 5177-5187, http://dx.doi.org/10.1007/s11356-013-1491-6.

[56] V. Hormazabal, I. Steffenak, M. Yndestad, A time and costeffective assay for the determination of residues of malachite green in fish tissues by HPLC, J. Liq. Chromatogr. 15 (1992) 2035-2044. 
[57] C. Novotný, N. Dias, A. Kapanen, K. Malachová, M. Vándrovcová, M. Itävaara, N. Lima, Comparative use of bacterial, algal and protozoan tests to study toxicity of azo- and anthraquinone dyes, Chemosphere 63 (2006) 1436-1442, http://dx.doi. org/10.1016/j.chemosphere.2005.10.002.

[58] L.A. Luna, T.H. Silva, R.F. Nogueira, F. Kummrow, G.A. Umbuzeiro, Aquatic toxicity of dyes before and after photo-Fenton treatment, J. Hazard Mater. 276 (2014) 332-338, http://dx.doi.org/10.1016/j.jhazmat.2014.05.047.

[59] M. Punzi, A. Anbalagan, R.A. Börner, B.-M. Svensson, M. Jonstrup, B. Mattiasson, Degradation of a textile azo dye using biological treatment followed by photoFenton oxidation: evaluation of toxicity and microbial community structure, Chem. Eng. J. 270 (2015) 290-299, http://dx.doi.org/10.1016/j.cej.2015.02.042.

[60] M. Punzi, F. Nilsson, A. Anbalagan, B.M. Svensson, K. Jönsson, B. Mattiasson, M. Jonstrup, Combined anaerobic-ozonation process for treatment of textile wastewater: removal of acute toxicity and mutagenicity, J. Hazard Mater. 292 (2015) 52-60, http://dx.doi.org/10.1016/j.jhazmat.2015.03.018.

[61] K. Paździor, J. Wrębiak, A. Klepacz-Smółka, M. Gmurek, L. Bilińska, L. Kos, J. SójkaLedakowicz, S. Ledakowicz, Influence of ozonation and biodegradation on toxicity of industrial textile wastewater, J. Environ. Manag. 15 (2017) 166-173, http://dx. doi.org/10.1016/j.jenvman.2016.06.055.

[62] N.C. Fernandes, L.B. Brito, G.G. Costa, S.F. Taveira, M.S.S. Cunha-Filho, G.A.R. Oliveira, R.N. Marreto, Removal of azo dye using Fenton and Fenton-like processes: evaluation of process factors by Box-Behnken design and ecotoxicity tests, Chem.-Biol. Interac. 291 (2018) 47-54, http://dx.doi.org/10.1016/j.cbi. 2018.06.003.

[63] R. Gopinathan, J. Kanhere, J. Banerjee, Effect of malachite green toxicity on non target soil organisms, Chemosphere 120 (2015) 637-644, http://dx.doi.org/10. 1016/j.chemosphere.2014.09.043.

[64] S. Nouren, H.N. Bhatti, M. Iqbal, I. Bibi, S. Kamal, S. Sadaf, M. Sultan, A. Kausar, Y. Safa, By-product identification and phytotoxicity of biodegraded Direct Yellow 4 dye, Chemosphere 169 (2017) 474-484, http://dx.doi.org/10.1016/j.chemosphere. 2016.11.080.

[65] J.S. Bae, H.S. Freeman, Aquatic toxicity evaluation of new direct dyes to the Daphnia magna, Dyes Pigments 73 (2007) 81-85, http://dx.doi.org/10.1016/j. dyepig.2005.10.015.

[66] E.M. Traudt, J.F. Ranville, J.S. Meyer, Effect of age on acute toxicity of cadmium, copper, nickel, and zinc in individual-metal exposures to Daphnia magna neonates, Environ. Toxicol. Chem. 36 (2017) 113-119 doi: 10.1002/etc. 3507. Epub 2016
Jul 21

[67] K.V. Brix, R.M. Gerdes, W.J. Adams, M. Grosell, Effects of copper, cadmium, and zinc on the hatching success of brine shrimp (Artemia franciscana), Arch. Environ. Contam, Toxicology 51 (2006) 580-583, http://dx.doi.org/10.1007/s00244-0050244-z.

[68] F.I. Vacchi, A.F. Albuquerque, J.A. Vendemiatti, D.A. Morales, A.B. Ormond, H.S. Freeman, G.J. Zocolo, M.V.B. Zanoni, G. Umbuzeiro, Chlorine disinfection of dye wastewater : implications for a commercial azo dye mixture, Sci. Total Environ. 442 (2013) 302-309, http://dx.doi.org/10.1016/j.scitotenv.2012.10.019.

[69] G. Frenzilli, M. Nigro, B.P. Lyons, The Comet assay for the evaluation of genotoxic impact in aquatic environments, Mutat. Res. 681 (2009) 80-92, http://dx.doi.org/ 10.1016/j.mrrev.2008.03.001.

[70] E.J. Calabrese, Hormesis: principles and applications, Homeopathy 104 (2015) 69-82, http://dx.doi.org/10.1016/j.homp.2015.02.007.

[71] E. Zeiger, G.R. Hoffmann, An illusion of hormesis in the Ames test: statistical significance is not equivalent to biological significance, Mutat. Res. Genet. Toxicol. Environ. Mutagen 746 (2012) 89-93, http://dx.doi.org/10.1016/j.mrgentox.2012. 03.008.

[72] K.E. Chapman, G.R. Hoffmann, S.H. Doak, G.J.S. Jenkins, Investigation of J-shaped dose-responses induced by exposure to the alkylating agent N-methyl-N-nitrosourea, Mutat. Res. Genet. Toxicol. Environ. Mutagen 819 (2017) 38-46, http:// dx.doi.org/10.1016/j.mrgentox.2017.05.002.

[73] E.J. Calabrese, L.A. Baldwin, Hormesis: U-shaped dose-response and their centrality in toxicology, Trends Pharmacol. Sci. 22 (2001) 286-291, http://dx.doi.org/10. 1016/S0165-6147(00)01719-3.

[74] E.J. Calabrese, Hormesis within a mechanistic context, Homeopathy 104 (2015) 90-96, http://dx.doi.org/10.1016/j.homp.2015.01.002.

[75] A. Kienzler, X. Tronchère, A. Devaux, S. Bony, Assessment of RTG-W1, RTL-W1, and PLHC-1 fish cell lines for genotoxicity testing of environmental pollutants by means of a Fpg-modified comet assay, Toxicol. Vitro 26 (2012) 500-510, http://dx.doi. org/10.1016/j.tiv.2012.01.001.

[76] A. Kienzler, S. Bony, A. Devaux, DNA repair activity in fish and interest in ecotoxicology: a review, Aquat. Toxicol. 134-135 (2013) 47-56, http://dx.doi.org/10. 1016/j.aquatox.2013.03.005.

[77] D.G. Walton, A.B. Acton, H.F. Stich, DNA repair synthesis in cultured mammalian and fish cells following exposure to chemical mutagens, Mutat. Res. 124 (1983) 153-161. 